
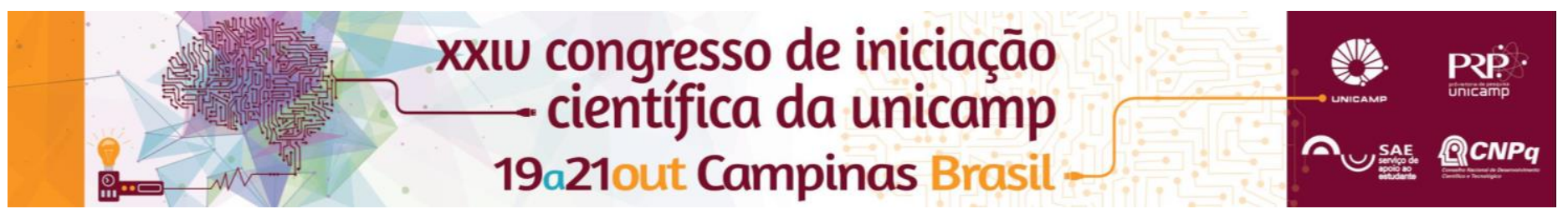

\title{
Um bárbaro na Antiguidade, um herói na modernidade: criação e utilização da figura de Armínius pelo $3^{\circ}$ Reich
}

\author{
Dominique G. C. Q. G. Thielemann
}

\begin{abstract}
Resumo
Este trabalho teve como meta analisar os usos e apropriações, por parte da Alemanha em sua formação como nação e as bases que deram para a ideologia Nazista (1933-1945) ganhar força, da figura de Arminius (c. 17 a.C. - 21 d.C.), general germânico da tribo de Cheruskes que comandou uma revolta contra os romanos no ano 9 d.C., por meio do Monumento Hermann, elaborado entre os anos de 1838 e 1875 no momento da Unificação Alemã, e reutilizado na formação de uma justificativa à ideologia Nazista. Esse monumento elaborado por Ernest Von Bandel e colocado na região ao sul da floresta de Teutoburg traz uma representação do general Arminius, personagem utilizado pelo nazismo como símbolo do povo alemão. Partindo então da ideia de que a ideologia nazista em diferentes momentos valeu-se e procurou legitimar seus pressupostos também por meio da cultura material, a pesquisa teve como intuito enteder de que modo os governos desses períodos se utilizaram dessa imagem, suas diferenças e semelhanças da história contada em diferentes períodos, como uma das justificativas da superioridade alemã frente a outros povos.
\end{abstract}

\section{Palavras-chave:}

1. Arminius, 2. Usos do Passado, 3. Alemanha

\section{Introdução}

A Alemanha, em sua formação, bem como nos períodos que a seguiram, se utilizou muitas vezes da História e da Arqueologia para dar forma a um passado comum entre seus habitantes, gerando uma identidade nacional que os uniria como um único povo. Uma dessas figuras históricas foi Arminius, guerreiro germânico que "libertou" o leste do Reno do poder romano, que foi utilizado, primeiramente, no período em que se formava o Império Alemão para representar a força do povo alemão contra um de seus principais adversários à época, a França, tanto que o monumento está voltado para a mesma e não para onde fica Roma, 0 inimigo original. Posteriormente, após a Primeira Guerra Mundial, essa figura perdeu muito do seu brilho e foi deixada de lado, mas com a ascensão do nazismo, a figura de Arminius ganhou um novo sentido: de que ele limpara as terras da Alemanha e as reerguera da miséria, bem como Hitler pretendia fazer aniquilando os judeus, os ciganos, os homossexuais e outras minorias, e também levantar o país da crise econômica e social vivida no período em que assumiu. Assim o objetivo principal da pesquisa foi entender as bases históricas, tanto clássicas quanto contemporâneas, que fizeram surgir a interpretação nazista e tentar analisá-la.

\section{Resultados e Discussão}

Durante o desenvolvimento da pesquisa pode-se notar que não há realmente nenhum documento descoberto da época em que a Batalha de Teutoburg ocorreu sobre a mesma, os autores que sobre ela escreveram são muito posteriores a ela e nenhum escreveu especificamente sobre ela, com exceção de Tácito que em seu livro Anais descreve por muitos capítulos sobre o desenvolvimento desde 0 inicio até o fim. Portanto, os textos, além de serem frutos do seu tempo, apresentam diversas informações, muitas vezes contraditórias entre si, que foi preciso serem analisadas com cuidado, sem deixar uma sobressair-se à outra em relevância.

Já os textos da atualidade, em sua maioria, trataram do período histórico em que a reutilização da figura do
Arminius foi mais evidente, século XIX (formação do Império Alemão) até o fim a Primeira Guerra Mundial, deixando muito a desejar quanto à volta da idealização durante a Alemanha Nazista.



Figura 1.Hermanndenkmal, Floresta de Teuteburgo, Alemanha.

\section{Conclusões}

A figura de Arminius foi de extrema importância para o desenvolvimento de uma identidade nacional, tanto na formação do país quanto durante o período Nazista, porém neste não se encontra muitos textos traduzidos, nem para o inglês nem para o português.

Por fim, seria necessário um desenvolvimento muito maior dessa pesquisa para se encontrar mais informações sobre os usos do passado desse personagem no período em específico. Utilizando métodos como entrevista com pessoas que vivenciaram a Alemanha Nazista de seu interior e ampliar a bibliografia para outras línguas, como o alemão e o italiano. 